\title{
Rediscovery of the Grey-winged Cotinga Tijuca condita in south-eastern Brazil
}

\author{
D. A. SCOTT and M. DE L. BROOKE
}

\begin{abstract}
Summary
The Grey-winged Cotinga Tijuca condita, previously known from a single specimen collected in 1942, was rediscovered near the type-locality in the coastal hill ranges of Rio de Janeiro state, south-eastern Brazil, in November 1980. Fieldwork at two sites in November/December 1980 and November 1981 revealed the presence of 10 individuals: one calling male and one female in cloud-forest at $1,320 \mathrm{~m}$ in the Serra do Tinguá; and six calling males, one female and one unsexed bird in cloud-forest at $1,830-2,000 \mathrm{~m}$ in the Serra dos Orgãos. Two females were netted, and two calling males were seen well in the field. The plumage of calling males resembled that of females, but was brighter with more grey on the face. The voice was described as an explosive sooee-wheee. The calling posture was similar to that of pihas Lipaugus, and there was no indication of any lekking behaviour. The species appears to have a very restricted distribution, but there is no indication that it is under threat at the present time.
\end{abstract}

O cotingídeo Tijuca condita, previamente conhecido de um único indivíduo coletado em 1942, foi redescoberto próximo a sua localidade tipo nas montanhas da costa do estado do Rio de Janeiro, no sudeste do Brasil, em novembro de 1980. Observações no campo em duas localidades em novembro/dezembro 1980 e novembro 1981 revelaram a presença de 1o individuos: um macho cantando e uma fêmea em uma floresta de neblina a $1,320 \mathrm{~m}$ na Serra do Tinguá; seis machos, uma fêmea e um indivíduo de sexo não determinado em uma floresta de neblina a 1,830-2,000 $\mathrm{m}$ na Serra dos Orgãos. Duas fêmeas foram capturadas em rede e dois machos foram bem observados no campo. A plumagem dos machos assemelha-se a das fêmeas, contudo mais brilhante e acinzentado na face. $O$ canto foi descrito como um explosivo sooee-wheee. A postura de canto foi semelhante à de outros cotingídeos Lipaugus e não há indícios de comportamento de leque. A espécie parece ter uma distribuição muito restrita, mas não há indícios de que essa espécie esteja ameaçada no momento.

\section{Introduction}

The Grey-winged Cotinga Tijuca condita was first collected in 1942 in the Serra dos Orgãos some $40-60 \mathrm{~km}$ north-east of Rio de Janeiro in south-eastern Brazil. The single specimen, a female, was mistakenly identified as a female Black-andgold Cotinga Tijuca atra, and placed with that species in the collection of the Department of Zoology in the University of São Paulo. Thirty years elapsed before anyone took serious note of the peculiarities of the specimen (Snow and Goodwin 1974), and it was not until 1980 that David Snow of the British Museum described the bird as a new species on the basis of morphology, plumage and feather protein analysis (Snow 1980). Snow assigned the new species to the genus Tijuca on the basis of a general resemblance in structure, propor- 
tions and female plumage to $T$. atra. The plumage of the unknown male remained a matter for speculation.

Almost exactly at the time of publication of the description of $T$. condita, we were carrying out a survey of the montane forest avifauna of Rio de Janeiro state in south-eastern Brazil as part of a project funded jointly by the British Ornithologists' Union and the World Wildlife Fund. Emphasis was given to assessing the status of threatened species and searching for several species, including $T$. condita, which had not been reported for many years. It was with some excitement, therefore, that we came upon $T$. condita on a forested hill range within sight of the city of Rio de Janeiro soon after arriving in Brazil. Preliminary accounts of this rediscovery were given in Snow (1982) and Scott and Brooke (1985). The present paper provides further information on the observations of 1980 , and includes details of observations made in the second season of fieldwork in 1981 .

\section{The rediscovery}

The first indication of the continued presence of Tijuca condita in Rio de Janeiro state was sudden and convincing: at 17 hoo on 15 November 1980 , a bird was found hanging in a mist-net set in low dense cloud-forest (elfin forest) on a ridge-top at about $1,320 \mathrm{~m}$ near the summit of the Serra do Tinguá range $\left(22^{\circ} 36^{\prime} \mathrm{S}\right.$ $43^{\circ} 27^{\prime} \mathrm{W}$ ), only $40 \mathrm{~km}$ north-west of Rio de Janeiro. The bird had an active brood-patch and was apparently an adult female. It was carefully examined in the hand, weighed and measured, and then released at the net site. Despite extensive searches at this locality and in other similar habitat in the Serra do Tingua (up to $1,370 \mathrm{~m}$ ) during the next two weeks, no further indication of the bird's presence was obtained.

On 30 November 1980, we moved from the Serra do Tinguá to Serra dos Órgãos National Park, where we remained until 28 December. During our four weeks in the park, we investigated all forest types from around the park entrance at $975 \mathrm{~m}$ to the summit of the highest peak, Da Pedro do Sino, at $2,263 \mathrm{~m}$, but paid special attention to the higher elevations where $T$. condita might be expected to occur. At 16 h3o on 5 December, on only our second excursion above the 1,500 $\mathrm{m}$ contour, we heard an unfamiliar call coming from a clump of trees on a knoll by the main summit trail at about $1,830 \mathrm{~m}$. The call was initially described as a short whistle "reminiscent of Tijuca atra but shorter, less plaintive, less pure and not nearly so loud" (D.A.S.).

A search of the clump of trees quickly located a $T$. condita similar in appearance to the female mist-netted two weeks previously in the Serra do Tinguá. The bird was foraging quietly just below the canopy of a tall tree. It remained almost stationary for long periods, then suddenly fluttered to a new perch. After some five minutes, it flew off through the canopy and was lost to sight. At no time was this bird seen calling; however, almost as soon as it had been lost to sight, calling began again from the area to which it had flown. A further search provided only a fleeting glimpse of the calling bird, and it could not be ascertained if this bird was in the same female-type plumage as the one seen moments earlier. A second bird was heard calling about $200 \mathrm{~m}$ away, but the inaccessibility of the site precluded any search for this individual. 
As $T$. condita was thought to be closely related to $T$. atra, it had been speculated that the new species would in all probability show strong sexual dimorphism like $T$. atra, and that the adult male condita might well be black with silver or white edgings to the wing and tail feathers. The observations on 5 December were inconclusive. It was not certain that the bird seen well was indeed the bird that had been calling and, even if it was, the possibility that it was an immature male, still in female-type plumage, could not be ruled out.

During the following 19 days, we visited this site (Site A, Figure 1) on 13 dates and spent a total of 71 hours listening for calling birds and trying to obtain better views of the species in the field. The calling bird on the forested knoll was heard on a number of occasions, but only glimpsed briefly on three dates, while the second bird, some $200 \mathrm{~m}$ further from the trail (Site B), was heard calling on four dates. A third calling bird was located on 7 December, near the upper limit of forest on a ridge-top at $1,980 \mathrm{~m}$ some $2 \mathrm{~km}$ further up the main trail (Site C). Sites B and C were both difficult of access, and neither of these calling birds was ever seen. By 24 December, the total observation time of $T$. condita in the field still amounted to only about seven minutes, and no bird had actually been observed making a call. Thus the question of the adult male plumage remained unresolved.

On 19 December, M. de L.B. explored the high plateau area beyond the end of the main trail and to the south-west of Da Pedro do Sino. He eventually located one $T$. condita calling in a region of ridges and gullies with scattered patches of elfin forest at about 1,935-2,000 m (Site D, Figure 2). Unfortunately,

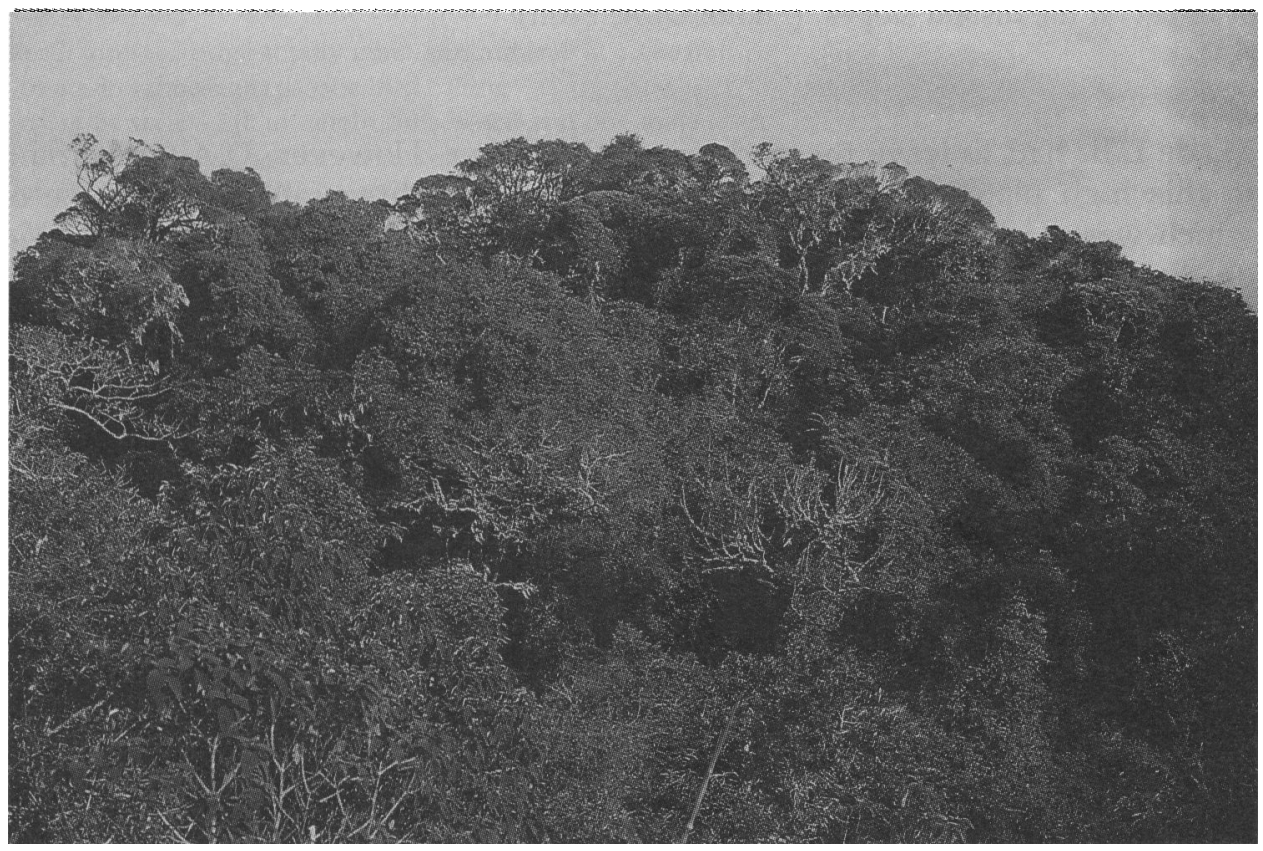

Figure 1. Site A: cloud-forest on a ridge-top at 1,830 $\mathrm{m}$ in Serra dos Orgãos National Park, site of a calling Grey-winged Cotinga. (Photo: D. A. Scott) 


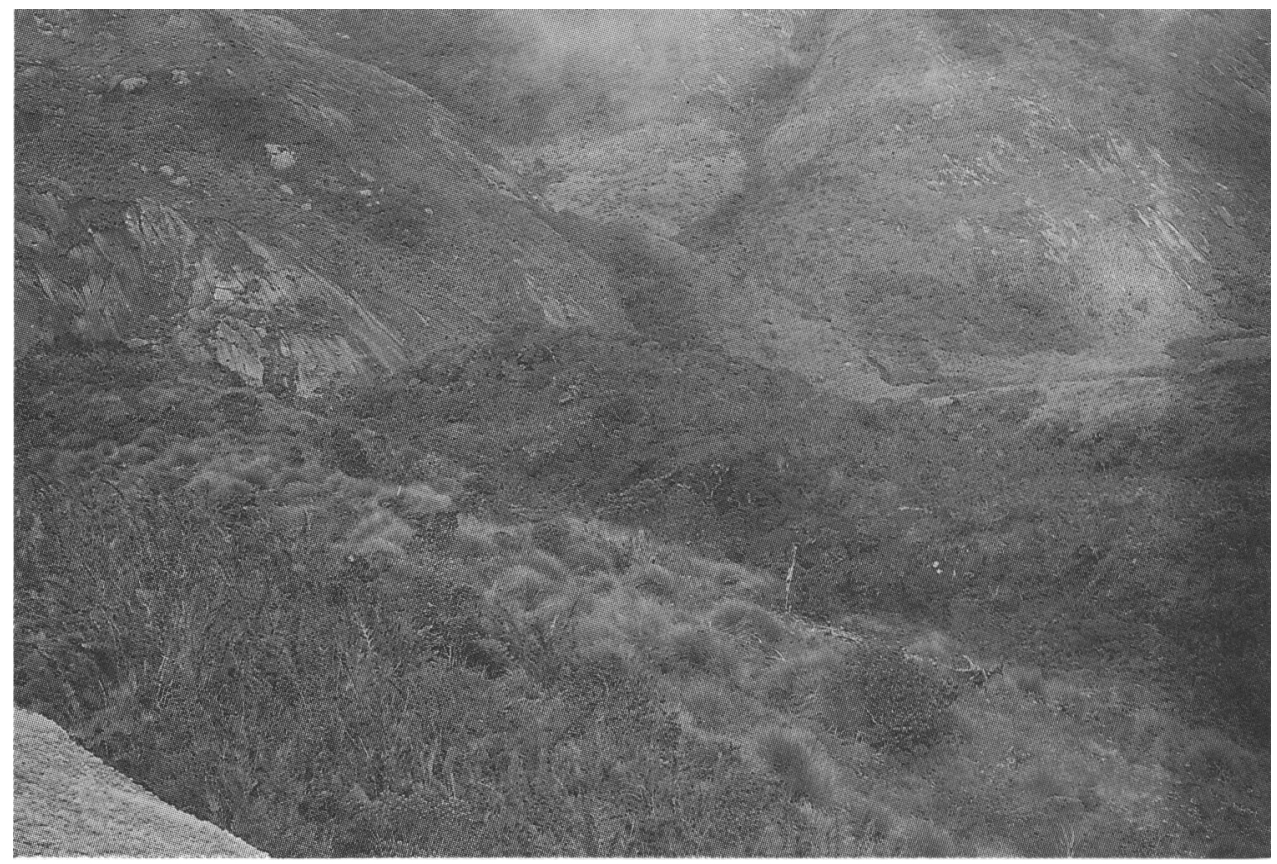

Figure 2. Site D: patches of elfin forest at $1,935^{-2,000} \mathrm{~m}$ on the high plateau of Serra dos Órgãos National Park. A calling Grey-winged Cotinga frequented the forested ridge in the middle distance; a second calling bird frequented the forested slope at the extreme right of the picture, beyond the ridge, and a third bird was heard calling from a patch of forest on the distant slopes. (Photo: D. A. Scott)

M. de L.B. had to leave the park on 21 December. However, D.A.S. returned to this high plateau on 25 December and located three calling birds, one of which was readily accessible and proved to be remarkably obliging. Extended observations were made of this bird on 25, 26 and 27 December. From its behaviour, it was clear that this was an adult male on territory. Its plumage was rather similar to that of the female mist-netted in the Serra do Tinguá, but distinctly brighter with more grey on the face, paler and more silvery outer webs to the wing and tail feathers, and brighter olive-yellow underparts.

D.A.S. had to leave the area on 28 December, and no further observations were made in $T$. condita habitat that season. However, the authors returned to Serra dos Órgãos National Park on 2 November 1981 in company with A. M. Hutson from the British Museum (Natural History). Birds were again located without difficulty at three of the previous year's sites. In particular at Site D on 23 November two birds were heard calling and one of these was observed at close range; a female was mist-netted and a fourth bird, either a female or an immature male, was watched foraging for small fruits in the canopy. Two birds were calling in this area on the 24th and 25th; one of the calling birds was seen on both dates and a presumed female was observed on the 24th. We spent the next few days working at lower elevations in the park, and planned to return 
Table 1 . Summary of records of Tijuca condita in 1980 and 1981

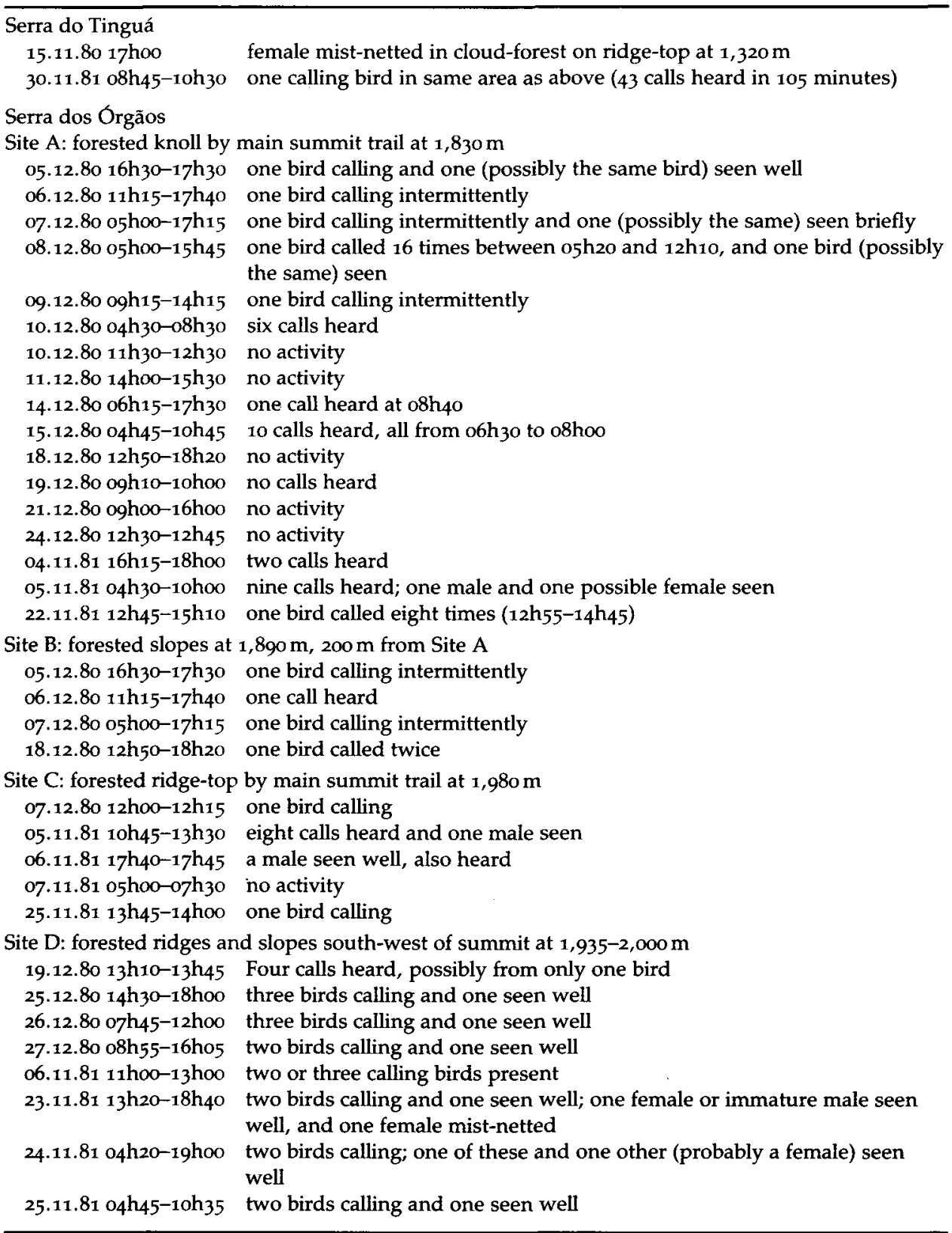

to the high plateau in early December. However, torrential rain on the 2nd caused a number of major landslides which completely blocked the trail up the mountain. As a consequence, no further fieldwork was possible in condita habitat that season. Indeed, it is only within the last few years that the trail has 
been re-opened and ornithologists are once again able to ascend to the elfin forest zone in search of $T$. condita.

M. de L.B. was able to pay a short visit to Serra do Tinguá between 27 November and 3 December 1981. A search of the area in which the female had been netted in November 1980 revealed the presence of a single calling bird, but this was not seen and no further evidence of the species's presence was obtained. Table 1 summarizes all records of $T$. condita at Serra do Tinguá and Serra dos Órgãos in 1980 and 1981.

\section{Description}

\section{Description of netted birds}

The following description is based on two mist-netted birds, both thought to be adult females. Upperparts from crown to rump olive-green. Forehead, lores and chin greyish with feathers tipped olive. Throat and ear-coverts dull olive; breast olive-yellow, becoming yellower on belly; undertail coverts yellow. All feathers of underparts with grey bases. Primaries, secondaries and tertials dark grey-brown or blackish-brown with silvery grey fringes. Greater and primary coverts grey-brown with pale grey fringes; median coverts greyish with olive fringes; lesser coverts olive with yellowish fringes. Tail blackish-brown with greyish outer webs to all feathers, but olive tinge at some angles on outer webs of central feathers.

Iris brown. Bill rather slender with a slight hook on the upper mandible. In the Tinguá bird, the bill was dark greyish with a yellow-olive cutting edge to the lower mandible. In the Serra dos Órgãos bird, the upper mandible was largely dark horn with a greenish-grey wedge at the base; the lower mandible was wholly greenish-grey. Gape bright orange. In the Tingua bird, the tarsi were dark horn and the soles of the feet orange; in the Serra dos Orgãos bird, the tarsi were greyish horn and the soles of the feet dull yellowish.

The Tinguá bird was in extensive body moult; the Serra dos Orgãos bird was moulting the feathers of the head, mantle and upper back. The Tinguá bird had a highly vascularized brood-patch; the Serra dos Orgãos bird had a bare and wrinkled brood-patch without pronounced vascularization. A few body feathers, two inner secondaries and a tail feather were collected and deposited at the British Museum (Natural History). The Serra dos Órgãos bird is illustrated in Figure 3.

Weights and measurements of the two mist-netted birds are given in Table 2, along with some measurements of the type-specimen.

\section{Field description}

Only two of the calling birds were seen sufficiently well for a detailed description of their plumage to be taken: the bird at Site A on 5 and 8 December 1980, and one of the birds at Site D on several occasions in 1980 and 1981 . The two birds were identical to one another and resembled females closely, although the face and throat of the males were greyer and the rest of the plumage dis- 


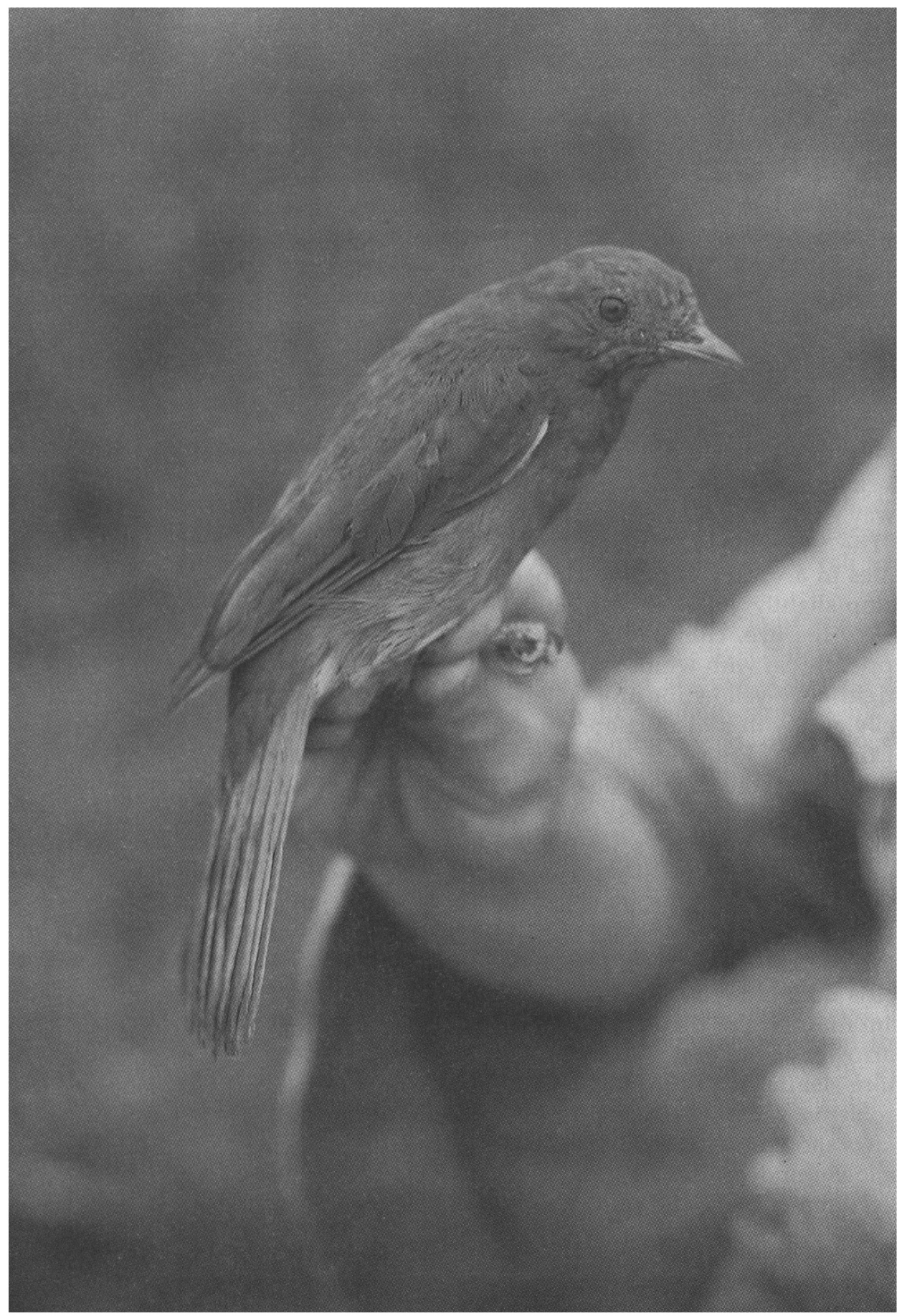

Figure 3. Female Grey-winged Cotinga mist-netted in Serra dos Orgãos National Park in November 1981. The grey edges to the tail feathers are particularly conspicuous. (Photo: D. A. Scott) 
Table 2. Measurements of Tijuca condita

\begin{tabular}{|c|c|c|c|c|c|}
\hline \multicolumn{6}{|c|}{ Type-specimen Serra dos Órgãos (1942) } \\
\hline Age/sex & female & \multirow{3}{*}{ Tail } & \multirow{3}{*}{$106 \mathrm{~mm}$} & \multirow{3}{*}{ Tarsus } & \multirow{3}{*}{$26.5 \mathrm{~mm}$} \\
\hline Wing & $122 \mathrm{~mm}$ & & & & \\
\hline Culmen & $14.5 \mathrm{~mm}$ & & & & \\
\hline \multicolumn{6}{|c|}{ Netted bird Serra do Tinguá, 15 November 1980, 17 hoo } \\
\hline Age/sex & adult female & Total length & $255 \mathrm{~mm}$ & Weight & $80 \mathrm{gm}$ \\
\hline Wing & $129 \mathrm{~mm}$ & Tail & $107 \mathrm{~mm}$ & Tarsus & $26 \mathrm{~mm}$ \\
\hline Bill to feathers & $21.5 \mathrm{~mm}$ & Bill to skull & $24 \mathrm{~mm}$ & & \\
\hline \multicolumn{6}{|c|}{ Netted bird Serra dos Orgãos, 23 November 1981, 14h3o } \\
\hline Age/sex & female & Total length & $255 \mathrm{~mm}$ & Weight & $87 \mathrm{gm}$ \\
\hline Wing & $130 \mathrm{~mm}$ & Tail & $109 \mathrm{~mm}$ & Tarsus & $29 \mathrm{~mm}$ \\
\hline Bill to feathers & $19.5 \mathrm{~mm}$ & Bill to skull & $22 \mathrm{~mm}$ & & \\
\hline
\end{tabular}

Taken from Snow 1982.

tinctly brighter. On one occasion a calling male was observed only a few metres away from its presumed mate, allowing direct comparison in the field.

The following description is a composite of descriptions taken on several dates in a variety of lights. Upperparts from crown to lower back olive-green; rump slightly yellower and with a faint apricot tinge. Forehead, lores, region below the eye, chin and upper throat dull grey, the feathers of the chin and upper throat with whitish tips giving a grizzled effect. Lower throat and breast bright olive-yellow (or dull yellow with an olive tinge), becoming yellower on belly and with a distinct apricot tinge in bright light, especially near the bend of the wing. Primaries, secondaries and tertials dark olive-brown or blackishbrown with conspicuous silver-grey outer webs appearing as a silver-grey panel on the closed wing. Lesser and median wing coverts mostly yellowish-olive. Tail relatively long and square; dark olive-brown or blackish-brown with greyish outer webs to all feathers. The silver-grey edges to the flight feathers were obvious even in flight, and the contrast between the dark wings and tail and yellowish-olive wing coverts, mantle, back and rump was striking when the bird was viewed in flight from behind.

Iris dark brown. Bill grey, slender and hooked. The bill appeared decidedly slim for a bird of this size, both from the side and from below, and was much narrower at the base than that of $T$. atra. Tarsi and feet dark horn, noticeably more slender than those of $T$. atra. Field identification of $T$. condita poses few problems, the only possible confusion being with a female $T$. atra. Reasonable views should reveal the distinctive greyish face, grey wing and tail edgings and yellower underparts of $T$. condita, and even in poor light the smaller size, generally slimmer build and noticeably finer bill should be apparent.

\section{Habitat}

All ten birds located in 1980 and 1981 were in extremely humid cloud-forest (elfin forest) rich in bromeliads and with a rather even canopy at 5-10 $\mathrm{m}$ above ground level. The two birds in the Serra do Tingua (at 1,340 $\mathrm{m}$ ) and the birds at Sites A, B and C in the Serra dos Orgãos (at 1,830 m, 1,890 m and 1,980 m 
respectively) were in exposed ridge-top situations, while the five birds at Site $D$ were located in small isolated patches of elfin forest on sheltered slopes in otherwise rather open areas of bamboo and tussock grass at 1,935-2,000 m, just above the main tree-line. The altitudinal ranges of $T$. condita and $T$. atra appear to be almost non-overlapping. In the Serra dos Órgãos, $T$. atra occurs commonly up to about $1,700 \mathrm{~m}$, but is seldom seen above $1,800 \mathrm{~m}$. On one occasion, however, a wandering band of three males and one female was watched for some 25 minutes moving through the territory of a calling $T$. condita at $1,830 \mathrm{~m}$. In the Serra do Tinguá, there was an active lek of $T$. atra about $120 \mathrm{~m}$ below the site where the female $T$. condita was netted, and on several occasions $T$. atra were seen moving over the ridge at $1,340 \mathrm{~m}$.

\section{Voice and behaviour}

The call of $T$. condita, although bearing a slight resemblance to that of $T$. atra, is quite distinctive, being of much shorter duration (about 1.25 seconds), more explosive and disyllabic, with emphasis on the second syllable. Possible renderings would be sooee-wheee or zuuee-ooeee. At any great distance, only the second syllable is audible as a short plaintive wheee. At very close range, the call has an explosive quality quite unlike that of T. atra.

Calling was heard sporadically throughout the day from first light at 04 h3o to dusk at $18 \mathrm{~h} 40$, but was most frequent in the morning between dawn and 09 ho, in the afternoon between 15 hoo and 17 hoo, and at dusk. Calling was heard under a variety of weather conditions - bright sunlight, strong winds, heavy rain and thick mist - but was most frequent during periods of calm with low overcast, mist or drizzle. At the height of their calling, undisturbed birds uttered one call every one to three minutes, although occasionally a sequence of four or five calls was given with gaps of only 25-40 seconds between calls. On one occasion, a bird was heard to make nine calls in four minutes, with intervals of 10 to 55 seconds between calls. During protracted observations at Site D on 26 December 1980, one calling bird uttered 34 calls in 78 minutes (o8h39-ogh 57) while its closest neighbour uttered 20 calls in 76 minutes (o8h20ogh36). Calling birds frequently changed their perches within a clearly defined patch of forest, uttering several calls from one perch, then moving on to another. Calling almost invariably occurred from a hidden perch within the dense forest canopy, and at the slightest disturbance the bird would fly off quickly to another hidden perch some distance away. On a few occasions, however, males were seen calling from an exposed perch on top of the canopy. This usually occurred during periods of low cloud and mist.

Calling birds held the body in an upright position, with the wings slightly spread and drooping, the tail slightly spread and pointing almost vertically downwards, and the feathers of the lower back and rump puffed out. On uttering the call, the neck was retracted, the breast feathers puffed out and the head thrown back in a double action, the first part of the call being uttered with the bill wide open at a 45 degree angle and the second part with the bill at an 80 degree angle. Then without pause, the head was brought back down to the horizontal position (Figure 4). The bright orange gape was conspicuous during the call. This head movement resembles rather closely that of calling pihas 


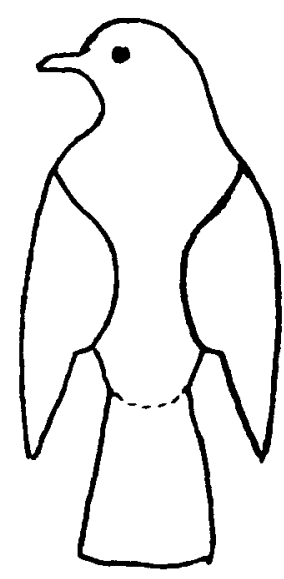

PRIOR TO CALLING

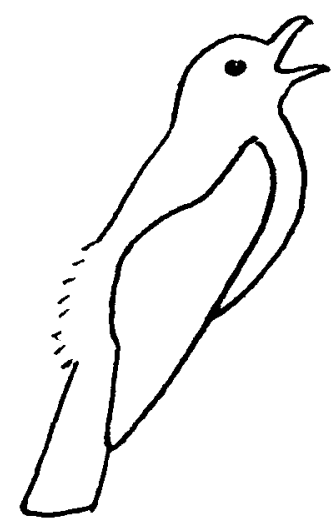

FIRST PART OF CALL

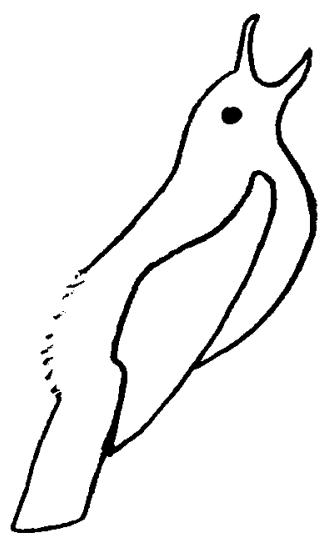

SECOND PART OF CALL

Figure 4. Calling posture of male Grey-winged Cotinga.

Lipaugus (particularly the Screaming Piha L. vociferans), and contrasts with the stationary head posture of calling $T$. atra.

Calling birds were extremely wary and elusive. Only three of the seven calling birds were ever seen, and one of these was seen on only one occasion as it chased an intruding male out of its territory (at Site D). There was no indication of any lekking behaviour; only single calling birds were recorded in the Serra do Tinguá and at Site C; the birds at Site A and Site B were never heard calling less than about $200 \mathrm{~m}$ apart, and the two closest birds at Site D were usually at least $150 \mathrm{~m}$ apart. Only on one occasion was one of the males at Site D seen to fly across an open valley into the territory of its nearest neighbour. This elicited an immediate response from the resident bird which flew out of the canopy and chased the intruder away. The most intensively studied male at Site D was only heard to call from within an isolated patch of elfin forest measuring about $100 \mathrm{~m}$ by $120 \mathrm{~m}(1.2 \mathrm{ha})$, and at no time was there any indication of a second calling bird in this patch of forest.

Because of the wariness of the birds, it was not possible to obtain extensive observations of general behaviour. On one occasion, a male was watched for over 10 minutes, initially exposed on the top of the canopy, delicately plucking small red berries and swallowing them whole, and occasionally calling. It later moved to a perch just below the canopy and sat there preening and occasionally calling. On another occasion, a bird was watched feeding on large purple berries in the canopy, and was seen to regurgitate and drop two large fruit stones.

\section{Discussion}

Although Snow (1980) assigned the Grey-winged Cotinga to the previously monotypic genus Tijuca, he subsequently noted that it seemed to be a link between T. atra and Lipaugus (Snow 1982). There were two grounds for this 
suggestion: the similarity in appearance of the two sexes of $T$. condita, a characteristic of Lipaugus, and the similarity in voice and calling behaviour between $T$. condita and some Lipaugus species. Indeed, it might well be that $T$. condita should more properly be assigned to Lipaugus.

With regard to the conservation of $T$. condita, it is clear that the species is rare and local; it occurs at very low density, and the total area of suitable habitat is small. Both sites at which the species has been recorded are afforded relatively good protection, the high elevation forests of the Serra do Tinguá as a water catchment area for the city of Rio de Janeiro, and the Serra dos Orgãos as a national park, established in 1939. We saw no indication of any threat to these high elevation forests during our surveys in 1980 and 1981, and there have been no reports of serious disturbance to these habitats since then. Indeed, the prime areas for $T$. condita in the Serra do Tinguá and Serra dos Orgãos are extremely difficult of access and apparently seldom visited by humans. We had to cut our own trail through dense montane forest and bamboo thickets to reach high elevations in the Serra do Tinguá, and some rock-climbing skills were required to reach Site D, the best area for the species in Serra dos Orgãos. Even the birds at Sites A, B and C, near the main trail to the summit of Serra dos Órgãos, became inaccessible in December 1981 following a series of landslides, and remained so for about seven years.

The main trail to the summit of the Serra dos Orgãos was re-opened in the late 1980s, and once again hikers and campers are visiting the high elevation forests, although it is doubtful if more than a tiny proportion ever proceed beyond the summit to Site $\mathrm{D}$ and other potential condita habitat elsewhere in the park. As far as is known, only two or three birdwatchers have managed to relocate $T$. condita since our observations in 1981. Observations were made on 19 and 20 July 1990 by N. J. and D. S. Gardner, who located two calling birds close to the main trail in the Serra dos Órgãos at about 1,980 m and 2,040 m respectively (Gardner and Gardner 1990). From their notes, it appears that the lower of these two birds was at Site $C$. The other bird was located in a sheltered valley with mature stunted trees and numerous bromeliads about $800 \mathrm{~m}$ further up the trail near the extreme upper limit of forest. This bird was eventually tracked down to a fruiting tree where it gave excellent sustained views. Gardner and Gardner suggested that disturbance from walkers and uncontrolled camp fires during the dry winter months could pose a threat to the species and its habitat, a view endorsed by a subsequent visitor, B. C. Forrester (in Collar et al. 1992).

The fieldwork in 1980 and 1981 revealed the presence of one calling bird in the Serra do Tinguá and six calling birds in the Serra dos Orgãos. Gardner and Gardner located an additional calling bird in the Serra dos Orgãos in 1990. Judging by the very limited amount of suitable habitat available for the species, it is difficult to see how the combined populations of $T$. condita in the Serra dos Orgãos and Serra do Tinguá could exceed more than a few hundred pairs, and it seems likely to be much less than this. However, there is no reason to believe that the species was ever much more numerous than at present, at least in historical times, and there do not appear to be any serious threats to the habitat. Thus, although $T$. condita certainly merits inclusion in the Red Data Book in the category "Rare" (as indeed it appears in Collar et al. 1992), there is no evidence 
to suggest that it is in imminent danger of extinction or indeed that it is even declining. It is doubtful, therefore, if any special conservation measures are required at the present time.

\section{Acknowledgements}

We wish to express our gratitude to the British Ornithologists' Union and World Wildlife Fund for providing the financial support for this study. We would like to thank Dante M. Teixeira and colleagues at the National Museum in Rio de Janeiro for providing logistic support for the fieldwork, and would also like to express our appreciation of Dr David Snow and the late Dr Helmut Sick for their valuable help and advice throughout.

\section{References}

Collar, N. J., Gonzaga, L. P., Krabbe, N., Madroño Nieto, A., Naranjo, L. G., Parker, T. A. and Wege, D. C. (1992) Threatened birds of the Americas: the ICBP/IUCN Red Data Book. Third edition (part 2). Cambridge, U.K.: International Council for Bird Preservation.

Gardner, N. J. and Gardner, D. S. (1990) Birding trip to Brazil: 1st May 1990-21st July 1990. Cyclostyled report, $72 \mathrm{pp}$.

Scott, D. A. and Brooke, M. de L. (1985) The endangered avifauna of southeastern Brazil: a report on the BOU/WWF Expeditions of $1980 / 81$ and 1981/82. Pp. 115-139 in A. W. Diamond and T. E. Lovejoy, eds. Conservation of tropical forest birds. Cambridge, U.K.: International Council for Bird Preservation (Techn. Publ. 4).

Snow, D. W. (1980) A new species of cotinga from south-eastern Brazil. Bull. Brit. Orn. Club 100: 213-215.

Snow, D. W. (1982) The cotingas. Oxford: Oxford University Press and British Museum (Natural History).

Snow, D. W. and Goodwin, D. (1974) The Black-and-gold Cotinga. Auk 91: 360-369.

DEREK A. SCOTT

Runagate, Far Green, Coaley, Dursley, Glos. GL11 5EL, U.K.

MICHAEL DE L. BROOKE

Department of Zoology, University of Cambridge, Downing Street, Cambridge $\mathrm{CB}_{2}{ }_{3} E$ ], U.K. 